\title{
Melt-Rock Reaction in the late stages of back arc spreading forming the Mado Megamullion in Shikoku Basin
}

\author{
A.SEN ${ }^{1}$, J.E.SNOW ${ }^{2}$, Y.OHARA ${ }^{3,4}$ \\ ${ }^{1}$ Earth and Atmospheric Sciences, University of Houston, TX \\ 77204, USA (asen6@central.uh.edu) \\ ${ }^{2}$ E235 Howe-Russell Building, Louisiana State University \\ Baton Rouge, Louisiana 70803, USA (jesnow@1su.edu) \\ ${ }^{3}$ Hydrographic and Oceanographic Department of Japan \\ Tokyo100-8932, Japan (ohara@jodc.go.jp) \\ ${ }^{4}$ Japan Agency for Marine-Earth Science and Technology, \\ Yokosuka 237-0061, Japan
}

Currently backarc lower crust and upper mantle have been studied in very few places. The Shikoku basin is an inactive backarc basin within the Philippine Sea plate. The Mado Megamullion (reported by YK18-07, KH-18-02 and YK19-04S cruises) is an oceanic core complex (OCC) in the Shikoku basin that provides an unique tectonic window to understand the processes operative in the lower crust/ upper mantle section at different stages during the evolution of the basin.

We sampled peridotites from the Hakuho Maru KH-18-02 cruise consisting of plagioclase bearing lherzolites and dunites. The plagioclase bearing peridotites contain pseudomorphed plagioclase as well as plagioclase-spinel intergrowths. Spinels show a wide range of variability with $\mathrm{Cr} \#(\mathrm{Cr} / \mathrm{Cr}+\mathrm{Al})$ ranging from 0.18 to 0.52 and $\mathrm{TiO}_{2}$ upto 0.24 $\mathrm{wt} \%$ from a single dredge site. They also preserve exsolution of $\mathrm{Cr}-$ spinels in pyroxenes (rare in oceanic mantle peridotites). Exsolution lamellae of clinopyroxene occurs in orthopyroxene and $\mathrm{Cr}$-rich oxides in clinopyroxenes occur in these lherzolites. These exsolutions are also present along deformed/mylonitized fabrics of orthopyroxene and clinopyroxene found in some of the samples.

The wide range of composition of the spinels, plagioclase pseudomorphs and plagioclase-spinel intergrowths coupled with the presence of mylonitic fabrics indicate melt stagnation and melt-rock interaction beneath the detachment fault zone. The presence of exsolution of different phases is an indication of exhumation of mantle peridotites to crustal depths. The Mado Megamullion therefore represents a section of the last phase of spreading where melt stagnation and melt rock reaction occurred. This exhumed large volumes of mantle rocks along a detachment fault at low spreading rates. This process is similar to the one operative in the Godzilla Megamullion (a typical end member in OCC formation) and is thus not restricted to the Parce Vela Basin which is also a part of the Philippine Sea plate. 
This abstract is too long to be accepted for publication.

Please revise it so that it fits into the column on one page. 